\title{
STUDIES ON THE STONEFLIES OF GEORGIA WITH THE DESCRIPTION OF A NEW SPECIES OF SOYEDINA RICKER, NEW STATE RECORDS AND AN ANNOTATED CHECKLIST
}

\author{
Chris J. Verdone', Boris C. Kondratieff ${ }^{1}$, R. Edward DeWalt ${ }^{2}$, and Eric J. South ${ }^{3}$ \\ ${ }^{1}$ Department of Bioagricultural Sciences and Pest Management, Colorado State University, \\ Fort Collins, Colorado, 80523, U.S.A. \\ E-mail: verdonec@gmail.com \\ E-mail: boris.kondratieff@colostate.edu \\ 2 University of Illinois, Prairie Research Institute, Illinois Natural History Survey, 1816 S Oak St., \\ Champaign, Illinois, 61820, U.S.A. \\ E-mail: dewalt@illinois.edu \\ ${ }^{3}$ Department of Entomology, University of Illinois at Urbana-Champaign, 320 Morrill Hall, 505 \\ S. Goodwin Ave., Urbana, Illinois, 61801, U.S.A. \\ E-mail: ejsouth@illinois.edu
}

\begin{abstract}
A new species of Soyedina Ricker is described, in addition to the listing of 24 new state records and the inclusion of an annotated checklist of species presently known from Georgia.
\end{abstract}

Keywords: Plecoptera, Nemouridae, Soyedina amicalola Verdone \& Kondratieff, 2017, Georgia, checklist

\section{INTRODUCTION}

Georgia stoneflies have received relatively little attention from entomologists in recent years. Although 14 valid species have their type localities in Georgia (Table 1, DeWalt et al. 2017), no systematic review of the stonefly fauna of the state has been published. Presently, only 75 species of stoneflies have been reported from Georgia (DeWalt et al. 2017). By comparison, 107 species have been reported from adjacent Alabama (Grubbs 2011), an area of comparable size.

Additions and modifications to the Georgia stonefly fauna have typically resulted from occasional taxonomic treatments, i.e., Taeniopteryx (Ricker \& Ross 1968), Allocapnia (Ross \& Ricker 1971), Acroneuria (Stark \& Gaufin 1976), Chloroperlinae (Surdick 1985), and Isoperla (Szczytko \& Kondratieff 2015). Previously, the greatest contribution to the stonefly fauna of Georgia resulted from Ricker (1952), in which 17 new state records were reported. The purpose of this paper is to present the description of a new species of Soyedina Ricker, report new state records and provide a preliminary checklist of the stoneflies of Georgia. 
Verdone, C.J., B. Kondratieff, R.E. DeWalt, and E. South. 2017. Studies on the stoneflies of Georgia with the description of a new species of Soyedina Ricker, new state records and an annotated checklist. Illiesia, 13(03):30-49. https://doi.org/10.25031/2017/13.03

Table 1. Species with type localities in Georgia.

\begin{tabular}{lll} 
Family & \multicolumn{1}{c}{ Species } & Type \\
\hline \hline Chloroperlidae? & Chloroperla cydippe Newman, 1839 & Nomen dubium \\
Leuctridae & Leuctra biloba Claassen, 1923 & Holotype \\
Leuctridae & Leuctra moha Ricker, 1952 & Holotype \\
Peltoperlidae & Tallaperla anna (Needham \& Smith, 1916) & Syntype \\
Peltoperlidae & Tallaperla cornelia (Needham \& Smith, 1916) & Holotype \\
Peltoperlidae & Tallaperla laurie (Ricker, 1952) & Holotype \\
Peltoperlidae & Viehoperla ada (Needham \& Smith, 1916) & Holotype \\
Perlidae & Acroneuria petersi Stark \& Gaufin, 1976 & Holotype \\
Perlidae & Beloneuria georgiana (Banks, 1914) & Holotype \\
Perlidae & Neoperla clymene (Newman, 1839) & Holotype \\
Perlidae & Perlinella drymo (Newman, 1839) & Holotype \\
Perlidae & Perlinella ephyre (Newman, 1839) & Holotype \\
Perlodidae & Clioperla clio (Newman, 1839) & Holotype \\
Perlodidae & Isoperla chickamauga Szczytko \& Kondratieff, 2015 & Holotype \\
Perlodidae & Remenus duffieldi Nelson \& Kondratieff, 1995 & Holotype \\
\hline
\end{tabular}

\section{METHODS}

Adult stoneflies were collected in March and May 2016 and February and May 2017 at locations in the five physiographic provinces of Georgia (Appalachian Plateau, Blue Ridge, Coastal Plain, Piedmont Plateau, and Ridge and Valley) (Fig. 1, Appendix A). Adult stoneflies were collected using a beating sheet (BioQuip, Rancho Dominguez, California, catalog \# 2840C) or handpicked from substrates using forceps. Specimens were preserved in $80 \%$ or $90 \%$ ethanol. Locality data were recorded directly using either Topo Maps version 1.16 for IPhone or a Garmin eTrex 20. Locality data for some records were georeferenced using ACME Mapper 2.1 (https://mapper.acme.com) or GEOLocate v. 3.22 (http://www.museum.tulane.edu/geolocate).

Additional material were examined from the C. P. Gillette Museum of Arthropod Diversity, Colorado State University, Fort Collins, Colorado (CSUC), Clemson University Arthropod Collection, Clemson, South Carolina (CUAC), the Illinois Natural History Survey, Champaign, Illinois (INHS) and Western Kentucky University, Bowling Green, Kentucky (WKUC). Specimens were inspected under a dissecting stereomicroscope. Color images were captured following the methods of Verdone and Kondratieff (2016). Image adjustments and measurements were made using Adobe Photoshop CS6 Extended.

\section{RESULTS}

A total of 1,776 adult stoneflies were examined in the study. The description of a new species of Soyedina, 24 new state records and an annotated checklist are presented below. Data for all specimens examined can be downloaded from a comma separated values file.

Soyedina amicalola Verdone \& Kondratieff, sp. n. http://1sid.speciesfile.org/urn:Isid:Plecoptera.speciesfil e.org:TaxonName:499523

(Figs. 2-8)

Material examined. Holotype $\partial^{\lambda}$, Georgia, Dawson Co., Little Amicalola Creek, Amicalola Falls State Park, N 34.57233, W 84.24107, 9 February 2017, C. Verdone, B. Kondratieff, (USNM); Paratypes: Same 


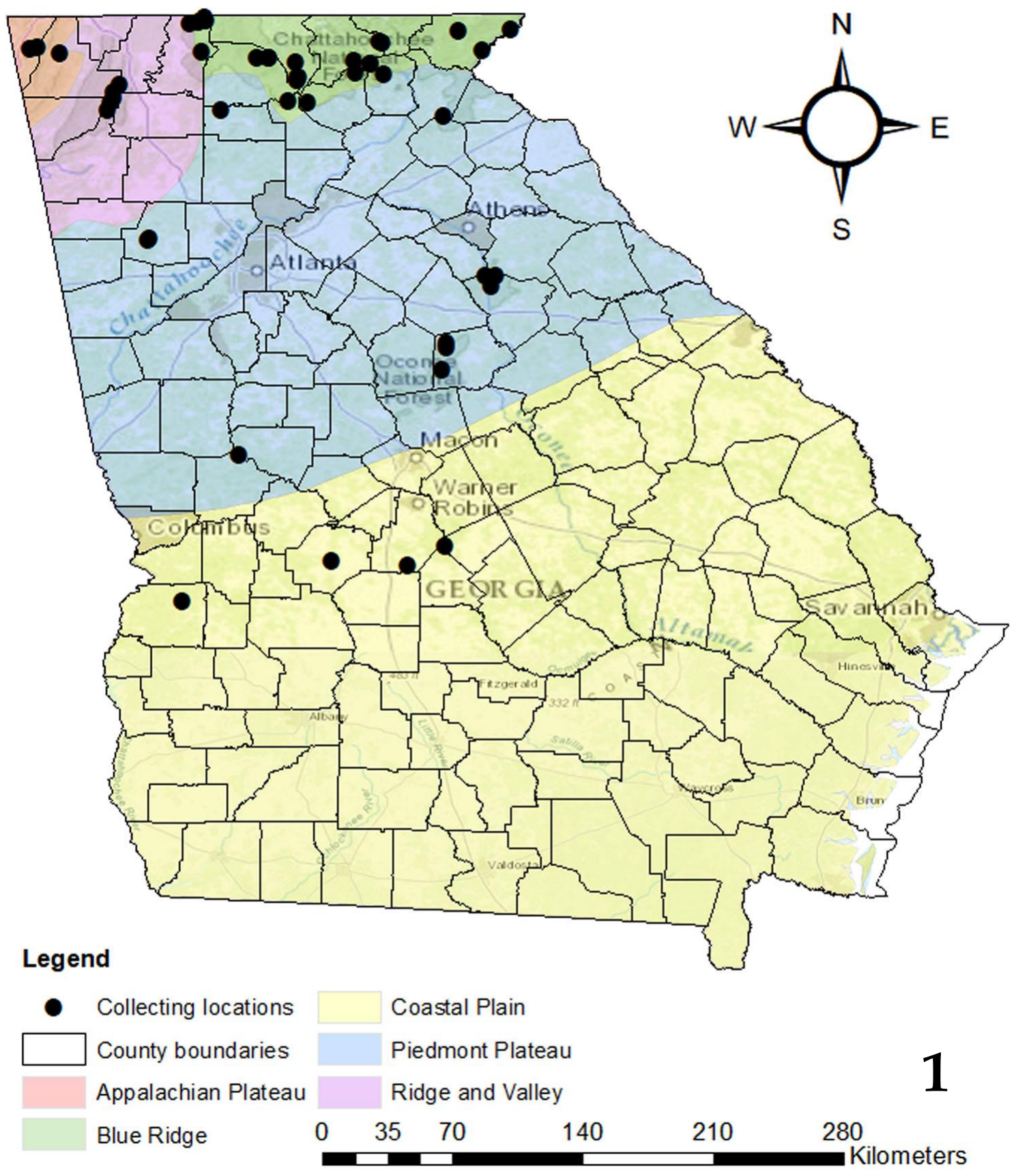

Fig. 1. Map of the physiographic provinces of Georgia and 2016-2017 collecting locations.

data as holotype, $\hat{0}$ (CSUC) (SCAN, CSUC_ENT0062195); Lumpkin Co., Frogtown Creek, Hwy 19, Desoto Falls Rec. Area, N 34.70649, W 83.91634, 10 February 2017, C. Verdone, B. Kondratieff, $\widehat{\jmath}$ (CSUC) (SCAN, CSU_ENT0062194). Distribution. USA - GA
Etymology. The name amicalola is a Cherokee word meaning "tumbling waters" and is a reference to the nearby waterfalls where this species was collected. We propose Georgia Forest Fly as the common name for this new species. 


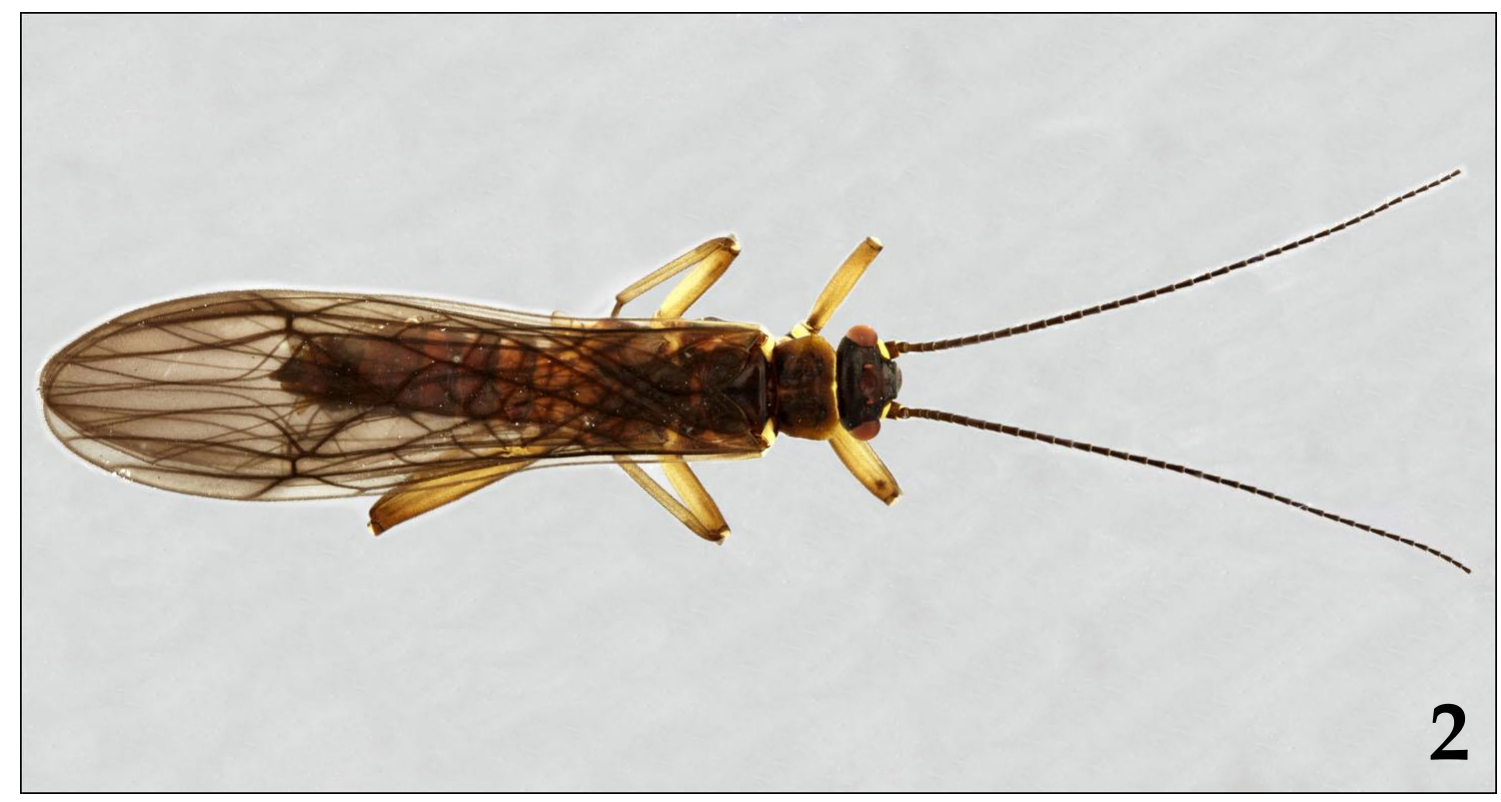

Fig. 2. Soyedina amicalola sp. n. male dorsal habitus.

Male. Macropterous. Length of forewings 7.8-7.9 $\mathrm{mm}(\mathrm{n}=3)$. Length of body $6.4-6.6 \mathrm{~mm}(\mathrm{n}=3)$. General body color brown (Fig. 2). Head dark brown; U-shaped carina between ocelli. Ocelli reddish. Legs light brown. Wings fumose. Venation typical for genus with A1 and A2 united near wing margin. Gills absent. Cerci membranous and one segmented with a sclerotized nipple-like process on apex. Hypoproct well developed, base covering medial $1 / 3$ of ninth sternum (Figs. 3, 6); apical half articulated, bent dorsad; small lateral projections covered in long setae produced at bend (Figs. 3, 5, 6, 8); apex lightly sclerotized, cylindrical. Vesicle long and thin, $3.5 \mathrm{X}$ as long as wide $(\mathrm{n}=3)$; narrow at base; widest at basal $1 / 4$; tapering to a narrowly rounded tip (Figs. 3, 6). Paraprocts with two lobes; inner lobes inconspicuous, small, narrow, flattened and lightly sclerotized. Outer lobes large, heavily sclerotized, narrowed at midlength; apical portion expanded posteriorly, mushroom-shaped in profile (Fig. 5, 8). Apical half of proximal side of outer lobes covered in sensilla, giving the appearance of a serrated edge on apical margin (Figs. 3-5, 8). Anterior apex broadly pointed and oriented slightly ventrad. Apex bisected by a thin sclerotized band (Figs. 5, 8). Epiproct typical for genus, asymmetrical with right half larger than left (Figs. 3, 4, 6, 7). Epiproct 2.5X as long as wide $(\mathrm{n}=3)$, when measured from base of ventral sclerite to epiproct apex and widest width. Lateral arms short, extending from the base of ventral sclerites to the base of the sclerotized portion of the dorsal sclerites (Fig. 7). Ventral sclerites elongate, width subequal, bearing small teeth on outer margin, tips rounded (Figs. 4, 7). Basal sclerites rectangular (Fig. 7). Basal portion of dorsal sclerite darkly sclerotized, triangular shaped, encircling basal cushion. Apical portion of dorsal sclerite lightly sclerotized; open throughout the apical $2 / 3$, which exposes the inner sclerotized structure.

Female. Unknown.

Diagnosis. Soyedina amicalola is most similar to $S$. kondratieffi Baumann \& Grubbs, 1996, S. merritti Baumann \& Grubbs, 1996 and S. washingtoni (Claassen, 1923) which also possess pointed paraproct apices, but can be separated by other details of the paraprocts. Soyedina amicalola has paraprocts that are mushroom-shaped with sensilla covering the apical half of the proximal side, giving the margin a serrated appearance. Whereas, $S$. kondratieffi, S. merritti and S. washingtoni do not 


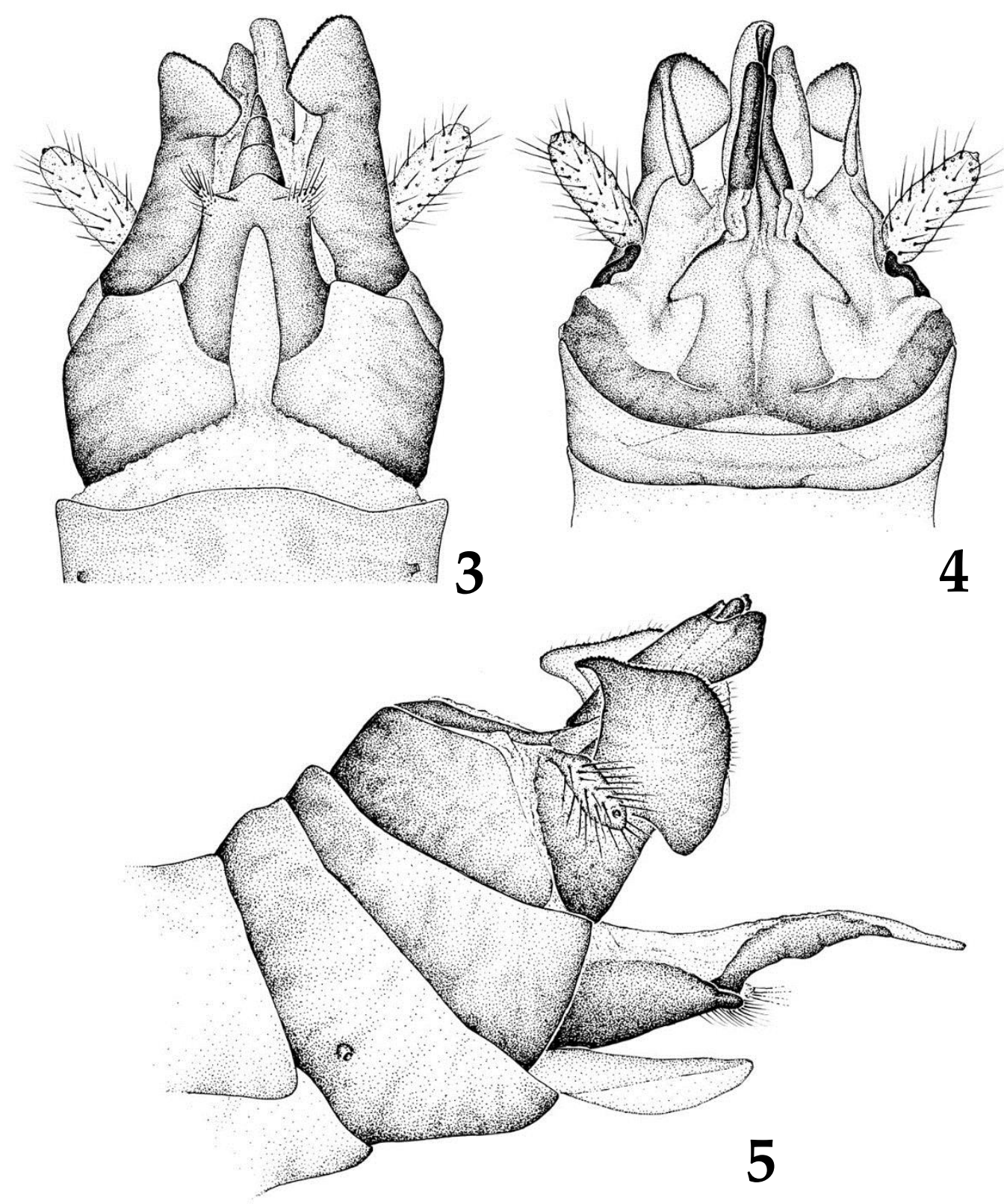

Figs. 3-5. Soyedina amicalola sp. n. 3. Male vesicle, ventral. 4. Male terminalia, dorsal. 5. Male terminalia, lateral.

exhibit the mushroom-shape and serrated appearance. In addition, S. amicalola is distinguished from S. kondratieffi by details of the epiproct. The epiproct of $S$. amicalola is asymmetrical, in contrast to the nearly symmetrical epiproct of $S$. kondratieffi.
Ongoing work by Scott Grubbs and Richard Baumann has found that details of epiprocts possess characters useful in grouping eastern Nearctic species of Soyedina (S. Grubbs, personal communication). Based on these characters, 
Verdone, C.J., B. Kondratieff, R.E. DeWalt, and E. South. 2017. Studies on the stoneflies of Georgia with the description of a new species of Soyedina Ricker, new state records and an annotated checklist. Illiesia, 13(03):30-49. https://doi.org/10.25031/2017/13.03

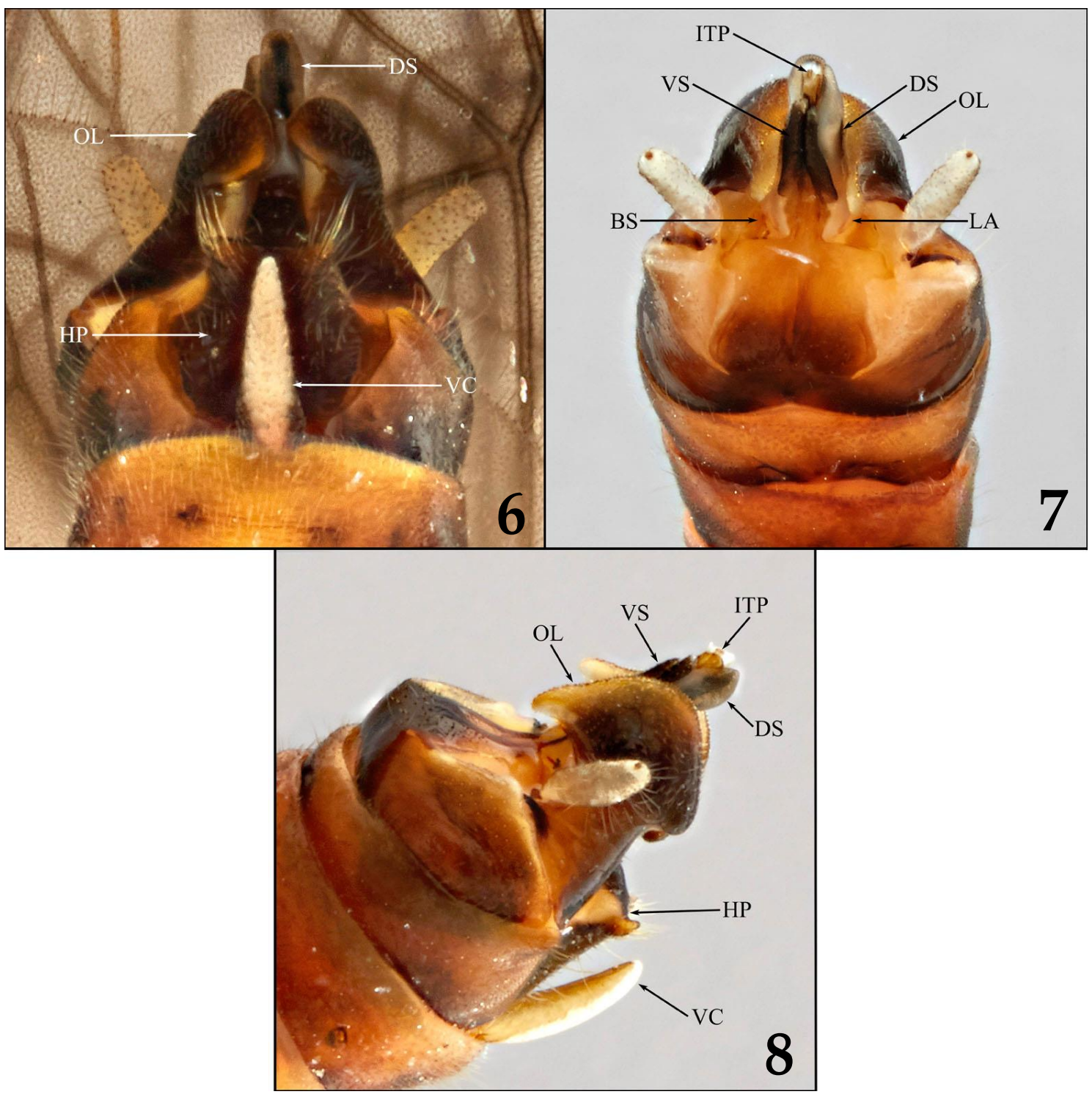

Figs. 6-8. Soyedina amicalola sp. n. 6. Male vesicle, ventral. 7. Male terminalia, dorsal. 8. Male paraproct, lateral. $\mathrm{BS}=$ basal sclerite, $\mathrm{DS}=$ dorsal sclerite, $\mathrm{HP}=$ hypoproct, $\mathrm{ITP}=$ inner tube-shaped process, $\mathrm{LA}=$ lateral arm, $\mathrm{OL}=$ outer paraproct lobe, $\mathrm{VC}=$ vesicle, $\mathrm{VS}=$ ventral sclerite .

S. amicalola is tentatively grouped with $S$. washingtoni, S. carolinensis (Claassen, 1923), and S. merritti, all of which possess relatively straight ventral sclerites and an inner tube-shaped process that is flared apically with the opening mostly centered, not strongly oriented to the left (Figs. 7, 8). Soyedina amicalola is easily distinguished from $S$. carolinensis which lacks pointed paraproct apices and is truncate posteriorly.

Additional material examined: Soyedina carolinensis: North Carolina, Buncombe Co., Blue Ridge Parkway, MP 360.3, BLRI, 2 May 2007, J. Robinson, $\hat{0}$, + (CSUC); Haywood Co., ATBI Plot, Cataloochee, GSMNP, 27 March-10 April 2002, P.E. Super, 2 $\hat{\gamma}$, + (CSUC); ATBI Plot, Purchase Knob, GSMNP, 27 March-10 April 2002, P.E. Super, J. Lowe, o (CSUC); Big Creek, GSMNP boundary, 11March 2008, C.R. Parker, ô (CSUC); Macon Co., stream at Wayah Crest Campground, Nantahala National Forest, 5 March 1991, R. Baumann, S. 
Verdone, C.J., B. Kondratieff, R.E. DeWalt, and E. South. 2017. Studies on the stoneflies of Georgia with the description of a new species of Soyedina Ricker, new state records and an annotated checklist. Illiesia, 13(03):30-49. https://doi.org/10.25031/2017/13.03

Clark, 60․ 2 ㅇ (CSUC). Soyedina kondratieffi: North Carolina, Macon Co., Upper Ball Creek, Coweeta Hydro Lab, (Malaise) 20 March-7 April 1984, A.D. Huryn, $\widehat{\jmath}$ (CSUC, paratype); Swain Co., Andrews Bald, ATBI plot, GSMNP, (Malaise), 16 March-24 April 2001, I.C. Stocks, J. Breeden, 40 , 4 우 (CSUC); Tennessee, Sevier Co., Rocky Spur of Roaring Fork, GSMNP, 25 March 1999, B. Kondratieff, $\widehat{o}$ (CSUC); Sams Creek, Stn 7, third trail crossing, ca. $100 \mathrm{~m}$ below mouth of Chuck Hollow, GSMNP, 1 February 1997, D. Etnier, ô (CSUC); Mannis Branch, ca. 12 mi. Little River, GSMNP, 25 February 1998, B. Hart, ô (CSUC). Soyedina merritti: Pennsylvania, Westmoreland Co., Maul Spring, Powdermill Nature Reserve, 19 March 1975, R.W. Baumann, O.S. Flint Jr., J.L. Sykora $\widehat{\jmath}$ (USNM, holotype). Soyedina sp.: Georgia, Rabun Co., Greasy Creek, North Germany Rd., N 34.9146, W 83.41972, 10 February 2017, C. Verdone, B. Kondratieff, o (CSUC). Soyedina washingtoni: New York, Delaware Co., spring-fed trib. to Emory Brook, Rt. 28 Fleischmanns, N 42.1511, W 74.5224, 27 May 2009, L. Myers, B. Kondratieff, 2 2 , 7 ㅇ (CSUC); Essex Co., Seep to North Fork Boquet River flowing off Noble Mountain, N 44.10820, W 73.69780, 9 May 2006, L.

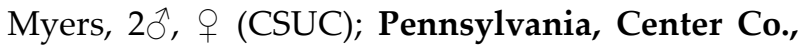
Big Poe Creek, Poe Paddy Dr., N 40.82972, W 77.44472, 29 March 1995, E.C. Masteller, Ô, o ; Erie Co., Sixmile Creek, H and B Morgan, 7 April 1986, E.C. Masteller, $\widehat{\partial}$ (CSUC); trib. to upper Fourmile Creek, 27 April 1987, E.C. Masteller, $3{ }^{\lambda}, 9$, 9 (CSUC); Fourmile Creek, Penn State Behrend Campus, N 42.12139, W 79.95416, 26 April 1981, E.C. Masteller, $\mathrm{d}, 3$ (CSUC); Forest Co., Indian Spring, old logging road, N 41.32791, 79.20204, 20 May 2009, S. Harris, ơ (CSUC).

Biological notes. The above records for S. amicalola are the first of this genus from Georgia. The two locations this species is known from are midelevation streams (630-792 m) with nearby seeps. Additional collections from these locations are needed to confirm the identity of the female. Other adult stoneflies collected with the holotype and paratypes were Allocapnia aurora Ricker, 1952 and Leuctra ferruginea (Walker, 1852).

New state records

\section{Nemouridae}

Amphinemura varshava (Ricker, 1952) was described from near Warsaw in northern Indiana and is a common inhabitant of cool streams in the Midwest region having been reported from Indiana, Illinois (DeWalt \& Grubbs 2011), Kentucky (Ricker 1952), Ohio (DeWalt et al. 2012), and Wisconsin (Grubbs et al. 2012). This species of Amphinemurinae was collected near the edge of Chattahoochee National Forest in the Ridge and Valley Physiographic Province of Georgia. This record constitutes a substantial southern range extension.

Material examined. Georgia, Whitfield Co., Dalton College Campus, [N 34.77335, W 85.00325], 29 April 1996, D. Yanega, 0 , + (INHS).

Prostoia completa (Walker, 1852) was described from Nova Scotia, Canada and has been reported from every southeastern state except Florida and Georgia (Grubbs et al. 2014). This species of Nemourinae was collected from two locations in the Piedmont Plateau Physiographic Province of Georgia. Similar to the records plotted in James (1972), these two localities represent the known southern limit of the distribution of this widespread species.

Material examined. Georgia, Putnam Co., Big Indian Creek, Big Indian Creek Rd., N 33.39687, W 83.47433, 11 February 2017, C. Verdone, B. Kondratieff, $5 \hat{\delta}, 3 q$ (CSUC); Murder Creek, Hillsboro Rd., N 33.26861, W 83.49739, 11 February 2017, C. Verdone, B. Kondratieff, $5 \hat{\jmath}, 4$ 우, 3N (CSUC).

\section{Leuctridae}

Leuctra carolinensis Claassen, 1923 was originally described from Black Mountain, North Carolina and has been reported from adjacent states of South Carolina and Tennessee (Unzicker \& McCaskill 1982, Stark et al. 1986, Kondratieff et al. 1995, Stewart \& Stark 2002). This species was collected from the type locality of Remenus duffieldi, a $2^{\text {nd }}$ order stream in the Blue Ridge Physiographic Province of Georgia.

Material examined. Georgia, Towns Co., Soapstone Creek, 2.9 km SE Brasstown Bald, N 
Verdone, C.J., B. Kondratieff, R.E. DeWalt, and E. South. 2017. Studies on the stoneflies of Georgia with the description of a new species of Soyedina Ricker, new state records and an annotated checklist. Illiesia, 13(03):30-49. https://doi.org/10.25031/2017/13.03

34.85588, W 83.78517, 17 May 2017, E.J. South, đ̋ (INHS).

Leuctra ferruginea (Walker, 1852) is widespread in the eastern United States and Atlantic Canada (Harrison \& Stark 2010). The only southeastern state from which this species had yet to be reported was Georgia. This species was collected from several locations in the Blue Ridge and Piedmont Plateau physiographic provinces of Georgia.

Material examined. Georgia, Dawson Co., Little Amicalola Creek, Amicalola Falls State Park, N 34.57233, W 84.24107, 9 February 2017, C. Verdone, B. Kondratieff, $3 \hat{\jmath}, 4$ ㅇ (CSUC); Fannin Co., [Hemptown Creek], 6 miles east of Morgantown, Rt. 76, [N 34.88985, W 84.19029], 30 January 1963, L.J. Stannard, W.S. Brooks, ơ (INHS); Fulton Co., Fort McPherson, [N 33.7077, W 84.43565], 24 June 1943, H. Hoogstraal, ô (INHS); Gilmer Co., Tails Creek, no location, 3 January 2013, C. Belcher $0^{*}, q$ (CSUC); Habersham Co., Tallulah River, Tallulah Falls, [N 34.73056, W 83.39444], 10 May 1944, T. H. Frison, H. H. Ross, ô (INHS); Lumpkin Co., Frogtown Creek, Hwy 19, Desoto Falls Rec. Area, N 34.70649, W 83.91634, 10 February 2017, C. Verdone, B. Kondratieff, $3 \hat{\partial}, 4$ 우 (CSUC); Rabun Co, Lake Burton, [N 34.79389, W 83.54056], 22 June 1940, H. H. Hobbs, ${ }^{\top}, 2$, (INHS); Union Co., Wolf Creek, Vogel State Park at Burnette Branch, N 34.76311, W 83.92679, 10 February 2017, C. Verdone, B. Kondratieff, $\widehat{\partial}, 2$, (CSUC).

Leuctra sibleyi Claassen, 1923 is widely distributed in the eastern United States and Atlantic Canada, but has not been reported from South Carolina, Georgia, or Florida. This species occurs in small streams to medium-sized rivers (Harper \& Hynes 1971) and emerges in the spring throughout its range. This species was collected from two $3^{\text {rd }}$ order streams in the Blue Ridge Physiographic Province of northern Georgia.

Material examined. Georgia, Fannin Co., Noontootla Creek, $10.4 \mathrm{~km}$ NNE Amicalola Mtn. at F.S. Rd. 58, N 34.68791, W 84.20182, 22 March 2016, E.J. South, ô (INHS). Gilmer Co., Turniptown Creek, US 76, [N 34.724009, W 84.43539], 23 April 2002, D. Etnier, $\hat{o}$ (CSUC).
Leuctra tenella (Provancher, 1878) was originally described from the vicinity of Quebec City, Quebec, Canada. Ricker (1952) subsequently designated a lectotype from Old Forge, New York. Leuctra tenella is the sister species of L. carolinensis (Grubbs 2015) and generally exhibits a more northeastern distribution. However, this species has been reported from Virginia (Kondratieff \& Kirchner 1987), Great Smoky Mountain National Park in North Carolina (Parker et al. 2007) and nearby locations in Haywood and Macon counties (Grubbs 2015). This species was collected from a $3^{\text {rd }}$ order stream in the Blue Ridge Physiographic Province of northern Georgia.

Material examined. Georgia, Union Co., Nottely River, 8.0 km NNW Pinnacle Mountain, N 34.74962, W 83.84646, 20 May 2017, E.J. South, $\precsim$ (INHS).

Paraleuctra sara (Claassen, 1937) is the only species of the genus that occurs in the eastern United States (Stark \& Kyzar 2001) and has been reported from adjacent states of Alabama (Grubbs 2011), North Carolina and South Carolina (Unzicker \& McCaskill 1982, Stark et al. 1986, Stewart \& Stark 1988, Kondratieff et al. 1995). This species was collected from a $3^{\text {rd }}$ order stream in the Blue Ridge Physiographic Province of northern Georgia.

Material examined. Fannin Co., Noontootla Creek, 10.4 km NNE Amicalola Mtn. at F.S. Rd. 58, N 34.68791, W 84.20182, 22 March 2016, E.J. South, ô, 2 (INHS). Towns Co., trib. to Owl Creek, Rte. 180, Chattahoochee National Forest, N 34.86261, W 83.76931, 7 March 2009, S.A. Grubbs, 0 ,, , , (WKUC).

Zealeuctra fraxina Ricker \& Ross, 1969 was described from Kentucky and is one of three Zealeuctra species that occurs in the Appalachian Mountains and has been reported from adjacent states of Tennessee and Alabama (Grubbs et al. 2013). This uncommon species was collected from two streams in Chattahoochee National Forest in the Ridge and Valley Physiographic Province of northwestern Georgia.

Material examined. Georgia, Floyd Co., Johns Creek, Everett Springs Rd., N 34.56416, W 85.10104, 8 February 2017, C. Verdone, B. Kondratieff, $4 \hat{\jmath}$, 우 (CSUC); Walker Co., trib. to Johns Creek, Keown Falls Trail, N 34.6138, W 85.08757, 8 February 2017, 
Verdone, C.J., B. Kondratieff, R.E. DeWalt, and E. South. 2017. Studies on the stoneflies of Georgia with the description of a new species of Soyedina Ricker, new state records and an annotated checklist. Illiesia, 13(03):30-49. https://doi.org/10.25031/2017/13.03

C. Verdone, B. Kondratieff, $\widehat{\jmath}$ (CSUC).

\section{Capniidae}

Allocapnia muskogee Grubbs \& Sheldon, 2008 was described from Cleburne and Clay counties Alabama and included a paratype male specimen from Lumpkin County, Georgia collected in 1964. Through the courtesy of S.A. Grubbs an additional male and three females of this uncommon Allocapnia from Towns County are listed below. Both Georgia locations are located in the Blue Ridge Physiographic Province.

Material examined. Georgia, Towns Co., tributary to High Shoals Creek, FR 283, Chattahoochee National Forest, N 34.80912, W 83.72552, 7 March 2009, S.A. Grubbs, ${ }^{\lambda}, 3$ ㅇ (WKUC).

Allocapnia tsalagi Grubbs, 2008 was described from a small spring in the Appalachian Plateau Physiographic Province of northeastern Alabama. This rare species was collected in the Ridge and Valley Physiographic Province in northern Georgia from a $1^{\text {st }}$ order stream $122 \mathrm{~km}$ east, and nearly at the same latitude as the type locality.

Material examined. Georgia, Murray Co., Head Branch, Old Hwy 2, E of Cisco at Lawground Branch, N 34.94523, W 84.72191, 2 January 2014, T.P. Belcher, $7 \hat{o}$ (CSUC).

Allocapnia unzickeri Ross \& Yamamoto, 1966 was described from Tennessee and is believed to be restricted to the Appalachian Plateau and Cumberland River Valley (Ross \& Ricker 1971). This former Tennessee endemic was collected from a $3^{\text {rd }}$ order stream in the Appalachian Plateau Physiographic Province in the northwest corner of Georgia, $16.9 \mathrm{~km}$ south of the Tennessee border.

Material examined. Georgia, Dade Co., Bear Creek, SR 189, Cloudland State Park, N 34.82823, W 85.45934, 8 February 2017, C. Verdone,B. Kondratieff, $\overbrace{}^{\lambda}, 2$, (CSUC).

Nemocapnia carolina Banks, 1938 has been reported from Quebec, Canada to Florida and west to central Arkansas (Stark et al. 2016). This species has been reported from the Wabash River drainage of Illinois and Indiana (Frison 1935), but is thought to be extirpated from those states (DeWalt \& Grubbs 2011). Nemocapnia carolina has been reported from several counties in adjacent states near the Georgia state line, but has not been formally reported from Georgia (Stark et al. 2016). This uncommon winter stonefly was collected from small and large order streams in the Piedmont Plateau and Coastal Plain physiographic provinces of Georgia.

Material examined. Georgia, Bleckley Co., Ocmulgee River, James Dykes Park, N 32.41439, W 83.48319, 12 February 2017 C. Verdone, B. Kondratieff, 20 $\hat{\jmath}, 14$ ㅇ (CSUC); Greene Co., Harris Creek, Nichols Rd., N 33.72509, W 83.23737, 11 February 2017, C. Verdone, B. Kondratieff, $\hat{0}$, $q$ (CSUC); Oconee River, Hwy 15, Oconee National Forest campground, N 33.72149, W 83.29095, 11 February 2017, C. Verdone, B. Kondratieff, $20 \hat{\jmath}, 8$ 우 (CSUC); Houston Co., Burnham Brand Creek, Hwy 26, SE of Elko, N 32.31585, W 83.66442, 12 February 2017, C. Verdone, B. Kondratieff, ㅇ (CSUC); Macon Co., Flint River, Montezuma Bluffs Park, N 32.33682, W 84.03118, 12 February 2017, C. Verdone, B. Kondratieff, $5 \lambda$, 5 ㅇ (CSUC); Putnam Co., Little River, Glades Rd., N 33.37238 W 83.4773, 11 February 2017, C. Verdone, B. Kondratieff, $3 \hat{\circ}, 2$ 우 (CSUC); Stewart Co., Hannahatchee Creek, Co. Rd. 150, N 32.14157, W 84.75333, 12 February 2017, C. Verdone, B. Kondratieff, $3 \hat{\jmath}, 3$ ㅇ (CSUC).

Paracapnia angulata (Hanson, 1961) is not common in the southern Appalachians, but is the most widespread Nearctic species in the genus. It has been recorded from Atlantic Canada to Arkansas and as far west as Colorado (Stark \& Baumann 2004). This species has been reported from Macon, Jackson and Transylvania counties in North Carolina near the Georgia state line (Beaty 2015). The records presented here were collected over 50 years ago, but were never reported.

Material examined. Georgia, Fannin Co., [Hemptown Creek], 6 miles east of Morgantown, Rt. 76, [N 34.88985, W 84.19029], 30 January 1963, L.J. Stannard, W.S. Brooks, 4 $\overbrace{}^{\lambda}$ (INHS); Union Co., [Youngcane Creek], $7 \mathrm{mi}$ west of Blairsville, Rt. 76, [N 34.83568, W 84.08412], 30 January 1963, L.J. Stannard, W.S. Brooks, $2 \hat{\jmath}$, ㅇ (INHS).

\section{Taeniopterygidae}


Verdone, C.J., B. Kondratieff, R.E. DeWalt, and E. South. 2017. Studies on the stoneflies of Georgia with the description of a new species of Soyedina Ricker, new state records and an annotated checklist. Illiesia, 13(03):30-49. https://doi.org/10.25031/2017/13.03

Oemopteryx contorta (Needham \& Claassen, 1925) was described from Jaffery, New Hampshire and has been reported from adjacent states of Alabama (Grubbs 2006), Tennessee (Nelson 1982), and North Carolina (Kondratieff et al. 1995). This species of Brachypterainae was collected from a $2^{\text {nd }}$ order stream in the Appalachian Plateau Physiographic Province in the northwest corner of Georgia.

Material examined. Georgia, Dade Co., Daniel Creek, Cloudland State Park, N 34.82457, W 85.49074, 8 February 2017, C. Verdone, B. Kondratieff, $2 \hat{\bigcirc}, 4$ ㅇ, 2N (CSUC).

Strophopteryx appalachia Ross \& Ricker, 1975 was originally described from Virginia and has been reported from adjacent states of North Carolina (Kondratieff et al. 1995), Tennessee, and South Carolina (Unzicker \& McCaskill 1982 Stark et al. 1986, Stewart \& Stark 1988, Kondratieff et al. 1995,). This species of Brachypterainae was collected from a $2^{\text {nd }}$ order stream in the Piedmont Plateau Physiographic Province, $51.5 \mathrm{~km}$ northwest of Atlanta, Georgia and the Chattooga River at the South Carolina border.

Material examined. Georgia, Paulding Co., Bluffy Creek, Hulsey Town Rd., N 33.8926, W 84.92486, 8 February 2017, C. Verdone, B. Kondratieff, $\widehat{0}, 1 \mathrm{~N}$ (CSUC). Rabun Co., Chattooga River, Hwy 76 Fishing Access, N 34.81404, W 83.30647, 10 February 2017, C. Verdone, B. Kondratieff, q (CSUC).

Strophopteryx fasciata (Burmeister, 1839) is widespread in the eastern United States and Atlantic Canada (DeWalt et al. 2017). This species has been reported from adjacent states of Alabama (Grubbs 2011), North Carolina and South Carolina (Unzicker \& McCaskill 1982, Stark et al. 1986, Stewart \& Stark 1988, Kondratieff et al. 1995). This species of Brachypterainae was collected from several locations in the Blue Ridge and Piedmont Plateau physiographic provinces of Georgia.

Material examined. Georgia, Murray Co., Conasauga River, Old Hwy 2, N 34.97461, W 84.64487, 9 February 2017, C. Verdone, B. Kondratieff, 20, 3 + (CSUC); Holly Creek, Camp Rd. Day Use Area, N 34.81181, W 84.6608, 9 February 2017, C. Verdone, B. Kondratieff, $\widehat{\jmath}$ (CSUC); Pickens
Co., Talking Rock Creek, $6.3 \mathrm{~km}$ WNW Talking Rock at GA-136, N 34.52624, W 84.57093, 18 February 2017, E.J. South, $\widehat{\jmath}$ (INHS); Putnam Co., Big Indian Creek, Big Indian Creek Rd., N 33.39687, W 83.47433, 11 February 2017, C. Verdone, B. Kondratieff, 2ð (CSUC); Murder Creek, Hillsboro Rd., N 33.26861, W 83.49739, 11 February 2017, C. Verdone, B. Kondratieff, $4 \hat{\circ}, 3$ ㅇ, $5 \mathrm{~N}$ (CSUC).

\section{Chloroperlidae}

Sweltsa mediana (Banks, 1911) was described from Black Mountain, North Carolina and has been subsequently reported from southwestern Virginia (Surdick 2004) to northwestern South Carolina (Grubbs 2011). Adults are typically active from late April to early July (Surdick 2004). This species of Chloroperlinae was collected from a $2^{\text {nd }}$ order stream in the Ridge and Valley Physiographic Province of northern Georgia.

Material examined. Georgia, Murray Co., Rock Creek, US 411, [N 34.69271, W 84.73510], 24 April 1999, D.A. Etnier, B. Haue, ô (CSUC).

\section{Perlidae}

Agnetina annulipes (Hagen, 1861) has been reported from Ohio (DeWalt et al. 2012), southern Indiana (DeWalt \& Grubbs 2011), and from Pennsylvania to Florida west to Louisiana (Stark 1986). Stark (1986) indicated that the distribution of this species was similar to Acroneuria arenosa (Pictet, 1841) and Paragnetina fumosa (Banks, 1902), both of which have been reported from Georgia (Ricker 1949, Stark \& Gaufin 1976). Specimens presented here were collected nearly 80 years ago by the late Dr. P.W. Fattig. Described as a "tireless collector" (Lund 1954) the former Emory University entomologist made many contributions to the documentation of various insect groups from Georgia.

Material examined. Georgia, Upson Co., [Flint River], Whispering Pines Tourism Camp, 13 mi. S Thomaston, [N 32.72215, W 84.23258], 8 June 1939, P.W. Fattig, $4 \hat{\jmath}, 3 q$ (INHS).

Neoperla coosa Smith \& Stark, 1998 was described from the Coosa River drainage in Chilton County, 
Verdone, C.J., B. Kondratieff, R.E. DeWalt, and E. South. 2017. Studies on the stoneflies of Georgia with the description of a new species of Soyedina Ricker, new state records and an annotated checklist. Illiesia, 13(03):30-49. https://doi.org/10.25031/2017/13.03

Alabama. This species has since been reported from adjacent states of North Carolina (Lenat et al. 2009) and Tennessee (DeWalt \& Heinold 2005). This species of Perlinae was collected in the Piedmont Plateau Physiographic Province of Georgia near the Fall Line, the escarpment separating the Piedmont Plateau from the Coastal Plain.

Material examined. Georgia, Upson Co., [Flint River], Whispering Pines Tourism Camp 13 mi. S Thomaston, [N 32.72215, W 84.23258], 8 June 1939, P.W. Fattig, 5ภ, 3 ㅇ (INHS).

Neoperla stewarti Stark \& Baumann, 1978 is widely distributed in the southeastern and midwestern United States and has been reported from adjacent states of Alabama, Tennessee (Stark 1990) and North Carolina (Lenat et al. 2009). This species was collected from a low elevation $4^{\text {th }}$ order stream in the Ridge and Valley Physiographic Province of northwestern Georgia.

Material examined. Georgia, Catoosa Co., Chickamauga Creek, Ringgold, [N 34.91525, W 85.12374], 14 June 1939, P.W. Fattig, §ో, ㅇ (INHS).

Perlesta decipiens (Walsh, 1862) is the most widespread Nearctic species in the genus, occurring from the sky islands of New Mexico and Arizona (Cary \& Jacobi 2008) to east of the Appalachian Mountains in Virginia (Stark 1989). This species was collected from a low elevation $4^{\text {th }}$ order stream in the Ridge and Valley Physiographic Province of northwestern Georgia.

Material examined. Georgia, Catoosa Co., Chickamauga Creek, Ringgold, [N 34.91525, W 85.12374], 14 June 1939, P.W. Fattig, 5ภ, + (INHS).

Perlesta ephelida Grubbs \& DeWalt, 2012 is widely distributed across the central and eastern United States and frequently occurs in lower elevation midsized streams (Grubbs \& DeWalt 2012). This species was collected from a low elevation $4^{\text {th }}$ order stream in the Ridge and Valley Physiographic Province of northwestern Georgia and an unspecified location near Ball Ground in the Piedmont Plateau Physiographic Province.

Material examined. Georgia, Catoosa Co., Chickamauga Creek, Ringgold, [N 34.91525, W
85.12374], 14 June 1939, P.W. Fattig, 6ภ, 7 ㅇ (INHS); Cherokee Co., Ball Ground [N 34.33727, W 84.37795], 27 June 1932, P.W. Fattig, ô (INHS).

Perlesta lagoi Stark, 1989 was originally described from Hinds County, Mississippi. This species has since been reported from adjacent states of Alabama (Grubbs 2012) and Tennessee (Kondratieff \& Kirchner 2002). This species was collected from a low elevation $3^{\text {rd }}$ order stream in the upper Coastal Plain Physiographic Province of Georgia.

Material examined. Georgia, Crawford Co., Culpepper Creek, 5 mi. SE Roberta, [N 32.69165, W 84.00792], 5 May 1939, P.W. Fattig, 2ð 39 (INHS).

Perlesta ouabache Grubbs \& DeWalt, 2011 is known only from Indiana. A single male specimen from an unknown location near Ball Ground, Georgia was examined that possesses characters consistent with P. ouabache. However, because of the disjunction of this record from the known distribution, fresh material is needed to confirm the presence of this species in Georgia.

Material examined. Georgia, Cherokee Co., Ball Ground [N 34.33727, W 84.37795], 27 June 1932, P.W. Fattig, ô (INHS).

Perlesta shawnee Grubbs \& Stark, 2004 was described from Illinois and Indiana and has subsequently been reported from Alabama, North Carolina, Virginia (Grubbs \& DeWalt 2008) and Kentucky (Grubbs 2012). This species was collected from two locations in the Piedmont Plateau Physiographic Province of Georgia.

Material examined. Georgia, Cherokee Co., Ball Ground [N 34.33727, W 84.37795], 27 June 1932, P.W. Fattig, $4 \AA$ (INHS); Fulton Co., Fort McPherson, [N 33.7077, W 84.43565], 3 June 1943, H. Hoogstraal, o (INHS); same location, 30 July 1943, H. Hoogstraal, $3 \hat{\jmath}$ (INHS).

\section{Perlodidae}

Cultus verticalis (Banks, 1920) has been reported from Atlantic Canada to Tennessee and North Carolina (Stark et al. 1988). This species often occurs in small to medium sized streams in the Appalachians (Myers \& Kondratieff 2009). It is 
Verdone, C.J., B. Kondratieff, R.E. DeWalt, and E. South. 2017. Studies on the stoneflies of Georgia with the description of a new species of Soyedina Ricker, new state records and an annotated checklist. Illiesia, 13(03):30-49. https://doi.org/10.25031/2017/13.03

reported from a $3^{\text {rd }}$ order stream in the Blue Ridge Physiographic Province of northern Georgia.

Material examined. Georgia, Fannin Co., Noontootla Creek, $10.4 \mathrm{~km}$ NNE Amicalola Mtn. at F.S. Rd. 58, N 34.68791, W 84.20182, 8 May 2016, E.J. South, $\widehat{o}$ (INHS).

Table 2 presents 100 species for Georgia and should be considered a work in progress as there are several genera that are likely underrepresented in our records, namely Leuctra Stephens, Isoperla Banks, Neoperla Needham and Perlesta Banks.

\section{DISCUSSION}

During this study, a male specimen of Perlesta, close to P. xube Stark \& Rhodes, 1997 and several males and females of Agnetina Klapálek, could not be satisfactorily determined to species. Additional properly prepared adult specimens of these stoneflies are required for specific determination. Perlesta in particular, must be collected alive and the aedeagus fully everted to allow for specific determination. Briefly, we (CJV \& BCK) collected live specimens in the field, brought them back to our lodging, and prepared these specimens under a dissecting microscope. Using wide-tipped forceps, we gently squeezed the aedeagus out to near its full extent, then submerged the specimen in near boiling water to fix the aedeagus in place. Often, some additional massaging of these specimens was required to more fully evert the terminal filament or dorsal caecum. Specimens were then preserved in $80 \%$ ethanol. Our coauthors employ slightly different methods, but the one described above worked well.
Stonefly species richness in the eastern United States has been attributed to the heterogeneity of lotic habitats associated with topography and the five major physiographic provinces (Kondratieff \& Kirchner 1987, Kondratieff et al. 2017): Appalachian Plateau, Blue Ridge, Coastal Plain, Piedmont Plateau, and Ridge and Valley (Woodward \& Hoffman 1991). Many of the conditions that have resulted in high species diversity in other eastern states are present in Georgia including all five physiographic provinces and relatively high topographic relief, which ranges from sea level to $1458 \mathrm{~m}$ (4784 ft.) at Brasstown Bald. Georgia is a state with potential for several additional new state records and undescribed species. The mountainous regions have been relatively well collected, but the Piedmont and Coastal Plain physiographic provinces, which cover the majority of the state, remain poorly surveyed.

Several of the species presented as new state records and in the checklist are historical. Local and statewide extirpation of plecopteran species have been documented in Illinois (DeWalt et al. 2005, DeWalt \& Grubbs 2011), Indiana (DeWalt \& Grubbs 2011), Michigan (Grubbs et al. 2012) and Ohio (DeWalt et al. 2012) As such, modern collections are needed to confirm the continued presence of species in this imperiled insect order. Entomologists interested in collecting stoneflies in Georgia are required to obtain collecting/research permits from the following agencies: United States Forest Service, Georgia Department of Natural Resources Parks, Recreation and Historic Sites Division, and Georgia Department of Natural Resources Law Enforcement Division. 
Verdone, C.J., B. Kondratieff, R.E. DeWalt, and E. South. 2017. Studies on the stoneflies of Georgia with the description of a new species of Soyedina Ricker, new state records and an annotated checklist. Illiesia, 13(03):30-49. https://doi.org/10.25031/2017/13.03

Table 2. List of Georgia stoneflies.

\begin{tabular}{|c|c|c|}
\hline Family & Species & First Reference \\
\hline \multirow[t]{8}{*}{ Nemouridae } & Amphinemura appalachia Baumann, 1996 & Baumann (1996) \\
\hline & Amphinemura delosa (Ricker, 1952) & Ricker (1952) \\
\hline & Amphinemura nigritta (Provancher, 1876) & Ricker (1952) \\
\hline & Amphinemura varshava (Ricker, 1952) & new state record \\
\hline & Amphinemura wui (Claassen, 1936) & Ricker (1952) \\
\hline & Prostoia completa (Walker, 1852) & new state record \\
\hline & Prostoia hallasi Kondratieff \& Kirchner, 1984 & Grubbs et al. (2014) \\
\hline & Soyedina amicalola Verdone \& Kondratieff sp. n. & \\
\hline \multirow[t]{9}{*}{ Leuctridae } & Leuctra alexanderi Hanson, 1941 & Kondratieff \& Nelson (1995) \\
\hline & Leuctra biloba Claassen, 1923 & Claassen (1923) \\
\hline & Leuctra carolinensis Claassen, 1923 & new state record \\
\hline & Leuctra ferruginea (Walker, 1852) & new state record \\
\hline & Leuctra moha Ricker, 1952 & Ricker (1952) \\
\hline & Leuctra sibleyi Claassen, 1923 & new state record \\
\hline & Leuctra tenella (Provancher, 1878) & new state record \\
\hline & Paraleuctra sara (Claassen, 1937) & new state record \\
\hline & Zealeuctra fraxina Ricker \& Ross, 1969 & new state record \\
\hline \multirow[t]{11}{*}{ Capniidae } & Allocapnia aurora Ricker, 1952 & Ricker (1952) \\
\hline & Allocapnia muskogee Grubbs \& Sheldon, 2008 & Grubbs \& Sheldon 2008 \\
\hline & Allocapnia mystica Frison, 1929 & Ross \& Ricker (1971) \\
\hline & Allocapnia recta (Claassen, 1924) & Ross \& Ricker (1971) \\
\hline & Allocapnia rickeri Frison, 1942 & Ross \& Ricker (1971) \\
\hline & Allocapnia tsalagi Grubbs, 2008 & new state record \\
\hline & Allocapnia unzickeri Ross \& Yamamoto, 1966 & new state record \\
\hline & Allocapnia virginiana Frison, 1942 & Ross \& Ricker (1971) \\
\hline & Allocapnia wrayi Ross, 1964 & Ross \& Ricker (1971) \\
\hline & Nemocapnia carolina Banks, 1938 & new state record \\
\hline & Paracapnia angulata (Hanson, 1961) & new state record \\
\hline \multirow[t]{8}{*}{ Taeniopterygidae } & Oemopteryx contorta (Needham \& Claassen, 1925) & new state record \\
\hline & Strophopteryx appalachia Ross \& Ricker, 1975 & new state record \\
\hline & Strophopteryx fasciata (Burmeister 1839) & new state record \\
\hline & Taeniopteryx burksi Ricker \& Ross, 1968 & Ricker \& Ross (1968) \\
\hline & Taeniopteryx lonicera Ricker \& Ross, 1968 & Ricker \& Ross (1968) \\
\hline & Taeniopteryx maura (Pictet, 1841) & Ricker \& Ross (1968) \\
\hline & Taeniopteryx parvula Banks, 1918 & Ricker \& Ross (1968) \\
\hline & Taeniopteryx ugola Ricker \& Ross, 1968 & Fullington \& Stewart (1980) \\
\hline \multirow[t]{4}{*}{ Chloroperlidae } & Alloperla atlantica Baumann, 1974 & Baumann (1974) \\
\hline & Alloperla chloris Frison, 1934 & Surdick (1985) \\
\hline & Alloperla idei (Ricker, 1935) & Surdick (1985) \\
\hline & Alloperla nanina Banks, 1911 & Needham \& Claassen (1925) \\
\hline
\end{tabular}


Verdone, C.J., B. Kondratieff, R.E. DeWalt, and E. South. 2017. Studies on the stoneflies of Georgia with the description of a new species of Soyedina Ricker, new state records and an annotated checklist. Illiesia, 13(03):30-49. https://doi.org/10.25031/2017/13.03

\begin{tabular}{|c|c|c|}
\hline & Alloperla petasata Surdick, 2004 & Surdick (2004) \\
\hline & Alloperla usa Ricker, 1952 & Ricker (1952) \\
\hline & Haploperla brevis (Banks, 1895) & Needham \& Claassen (1925) \\
\hline & Suwallia marginata (Banks, 1897) & Surdick (1985) \\
\hline & Sweltsa lateralis (Banks, 1911) & Needham \& Claassen (1925) \\
\hline & Sweltsa mediana (Banks, 1911) & new state record \\
\hline & Sweltsa voshelli Kondratieff \& Kirchner, 1991 & Surdick (2004) \\
\hline Perlidae & Acroneuria abnormis (Newman, 1838) & Berner (1948) \\
\hline & Acroneuria arenosa (Pictet, 1841) & Stark \& Gaufin (1976) \\
\hline & Acroneuria arida (Hagen, 1861) & Frison (1942) \\
\hline & Acroneuria carolinensis (Banks, 1905) & Stark (2004) \\
\hline & Acroneuria evoluta Klapálek, 1909 & Frison (1942) \\
\hline & Acroneuria filicis Frison, 1942 & Stark \& Gaufin (1976) \\
\hline & Acroneuria perplexa Frison, 1937 & Stark \& Gaufin (1976) \\
\hline & Acroneuria petersi Stark \& Gaufin, 1976 & Stark \& Gaufin (1976) \\
\hline & Agnetina annulipes (Hagen, 1861) & new state record \\
\hline & Agnetina flavescens (Walsh, 1862) & Stark (1986) \\
\hline & Attaneuria ruralis (Hagen, 1861) & Berner (1948) \\
\hline & Beloneuria georgiana (Banks, 1914) & Banks (1914) \\
\hline & Beloneuria stewarti Stark \& Szczytko, 1976 & Stewart \& Stark (1993) \\
\hline & Eccoptura xanthenes (Newman, 1838) & Newman (1838) \\
\hline & Neoperla clymene (Newman, 1839) & Newman (1839) \\
\hline & Neoperla coosa Smith \& Stark, 1998 & new state record \\
\hline & Neoperla stewarti Stark \& Baumann, 1978 & new state record \\
\hline & Paragnetina fumosa (Banks, 1902) & Ricker (1949) \\
\hline & Paragnetina immarginata (Say, 1823) & Needham \& Claassen (1925) \\
\hline & Paragnetina kansensis (Banks, 1905) & Berner (1948) \\
\hline & Perlesta decipiens (Walsh, 1862) & new state record \\
\hline & Perlesta ephelida Grubbs \& DeWalt, 2012 & new state record \\
\hline & Perlesta lagoi Stark, 1989 & new state record \\
\hline & Perlesta placida (Hagen, 1861) & Berner (1948) \\
\hline & Perlesta shawnee Grubbs \& Stark, 2004 & new state record \\
\hline & Perlinella drymo (Newman, 1839) & Newman (1839) \\
\hline & Perlinella ephyre (Newman, 1839) & Newman (1839) \\
\hline Perlodidae & Clioperla clio (Newman, 1839) & Newman (1839) \\
\hline & Cultus decisus isolatus (Banks, 1920) & Ricker (1952) \\
\hline & Cultus verticalis (Banks, 1920) & new state record \\
\hline & Diploperla duplicata (Banks, 1920) & Ricker (1952) \\
\hline & Helopicus bogaloosa Stark \& Ray, 1983 & Stark \& Ray (1983) \\
\hline & Helopicus subvarians (Banks, 1920) & Ricker (1952) \\
\hline & Isoperla bellona Banks, 1911 & Needham \& Claassen (1925) \\
\hline & Isoperla chickamauga Szczytko \& Kondratieff, 2015 & Szczytko \& Kondratieff (2015) \\
\hline & Isoperla dicala Frison, 1942 & Szczytko \& Kondratieff (2015) \\
\hline
\end{tabular}


Verdone, C.J., B. Kondratieff, R.E. DeWalt, and E. South. 2017. Studies on the stoneflies of Georgia with the description of a new species of Soyedina Ricker, new state records and an annotated checklist. Illiesia, 13(03):30-49. https://doi.org/10.25031/2017/13.03

Isoperla frisoni Illies, 1966

Isoperla holochlora Klapálek, 1923

Isoperla lenati Szczytko \& Kondratieff, 2015

Isoperla nelsoni Szczytko \& Kondratieff, 2015

Malirekus hastatus (Banks, 1920)

Remenus bilobatus (Needham \& Claassen, 1925)

Remenus duffieldi Nelson \& Kondratieff, 1995

Yugus arinus (Frison, 1942)

Yugus bulbosus (Frison, 1942)

Peltoperlidae Tallaperla anna (Needham \& Smith, 1916)

Tallaperla cornelia (Needham \& Smith, 1916)

Tallaperla laurie (Ricker, 1952)

Tallaperla maria (Needham \& Smith, 1916)

Viehoperla ada (Needham \& Smith, 1916)

Pteronarcyidae Pteronarcys biloba Newman, 1838

Pteronarcys dorsata (Say, 1823)

Pteronarcys scotti Ricker, 1952
Szczytko \& Kondratieff (2015)

Ricker (1938)

Szczytko \& Kondratieff (2015)

Szczytko \& Kondratieff (2015)

Ricker (1952)

Ricker (1952)

Kondratieff \& Nelson (1995)

Ricker (1952)

Ricker (1952)

Needham \& Smith (1916)

Needham \& Smith (1916)

Ricker (1952)

Ricker (1952)

Needham \& Smith (1916)

Ricker (1952)

Nelson \& Hanson (1971)

Ricker (1952)

\section{ACKNOWLEDGEMENTS}

We thank Chip Belcher for providing the Allocapnia tsalagi record, Dr. Mike Ferro, Clemson University, Clemson, South Carolina and Dr. Oliver Flint, Smithsonian Institution, Washington, DC, for loaning specimens, the United States Forest Service and the Georgia Department of Natural Resources for providing the necessary permits required to collect insects in the state of Georgia. Dr. Scott Grubbs and an anonymous reviewer are thanked for providing helpful comments that improved the manuscript. We especially thank Mike Kippenhan, Portland, Oregon, for preparing the illustrations.

\section{REFERENCES}

Banks N. 1914. New neuropteroid insects, native and exotic. Proceedings of the Academy of Natural Sciences of Philadelphia, 1:608-632.

Baumann, R.W. 1974. What is Alloperla imbecilla (Say)? Designation of a neotype, and a new Alloperla from eastern North America (Plecoptera: Chloroperlidae). Proceedings of the Entomological Society of Washington, 87:257264.

Baumann, R.W. \& S.A. Grubbs. 1996. Two new species of Soyedina (Plecoptera: Nemouridae) from the Appalachian Mountains. Entomological News, 107(4):220-224. http://www.biodiversitylibrary.org/page/2700498 Beaty, S.R. 2015. The Plecoptera of North Carolina: A biologist's handbook for the identification of stonefly nymphs with standard taxonomic effort levels. Version 4.0. North Carolina Department of Environmental Quality, Division of Water Resources, Biological Assessment Branch. Raleigh, North Carolina. iv + 91 pp. https://ncdenr.s3.amazonaws.com/s3fs-public/Water Quality/Environmental Sciences/BAU/Benthos Reference/BAB Taxonomy Doc - Plecoptera version 204.1- complete.pdf

Berner, L. 1948. Records of stoneflies from Florida (Plecoptera). The Florida Entomologist, 31(1):2123.

Cary, S.J. \& G.Z. Jacobi. 2008. Zoogeographic affinities of southwestern USA Plecoptera. Pp.133-157. In: International advances in the ecology, zoogeography, and systematics of mayflies and stoneflies. F.R. Hauer, J.A. Stanford \& R.L. Newell (Eds.) University of California Press, 422 pp.

Claassen, P.W. 1923. New species of North American Plecoptera. The Canadian Entomologist, 55(12):281-292.

DeWalt, R.E. \& B.D. Heinold. 2005. Summer emerging Ephemeroptera, Plecoptera, and Trichoptera of Abrams Creek, Great Smoky 
Verdone, C.J., B. Kondratieff, R.E. DeWalt, and E. South. 2017. Studies on the stoneflies of Georgia with the description of a new species of Soyedina Ricker, new state records and an annotated checklist. Illiesia, 13(03):30-49. https://doi.org/10.25031/2017/13.03

Mountains National Park. Proceedings of the Entomological Society of Washington, 107(1):3448. http://www.biodiversitylibrary.org/page/32142754

DeWalt, R.E. \& S.A. Grubbs. 2011. Updates to the stonefly fauna of Illinois and Indiana. Illiesia, 7(3):31-50. http://illiesia.speciesfile.org/papers/ Illiesia07-03.pdf

DeWalt, R.E., C. Favret \& D.W. Webb. 2005. Just how imperiled are aquatic insects? A case study of stoneflies (Plecoptera) in Illinois. Annals of the Entomological Society of America, 98(6):941-950.

DeWalt, R.E., M.D. Maehr, U. Neu-Becker \& G. Stueber. 2017. Plecoptera Species File Online. Version5.0/5.0. http://Plecoptera.SpeciesFile.org/ (Accessed 24 February 2017)

DeWalt, R.E., Y. Cao, T. Tweddale, S. Grubbs, L. Hinz, M. Pessino \& J. Robinson. 2012. Ohio USA stoneflies (Insecta, Plecoptera): species richness estimation, distribution of functional niche traits, drainage affiliations, and relationships to other states. ZooKeys, 178, p.1. https://www.ncbi.nlm.nih.gov/pmc/articles/PM C3317619/pdf/ZooKeys-178-001.pdf

Frison, T.H. 1935. The stoneflies, or Plecoptera of Illinois. Illinois Natural History Survey Bulletin, 20:281-467. http://www.nativefishlab.net/library /textpdf/18843.pdf

Frison, T.H. 1942. Studies of North American Plecoptera with special reference to the fauna of Illinois. Illinois Natural History Survey Bulletin, 21:78-99.

Fullington, K.E. \& K.W. Stewart. 1980. Nymphs of the stonefly genus Taeniopteryx (Plecoptera: Taeniopterygidae) of North America. Journal of the Kansas Entomological Society, 53:237-259.

Grubbs, S.A. 2006. Allocapnia sano, a new species of snowfly (Plecoptera: Capniidae) from Alabama, USA, plus six new state records. Zootaxa, 1197(1):39-43. https://www.researchgate.net/ profile/Scott_Grubbs/publication/228919016

Grubbs, S.A. 2011. A review of stonefly (Insecta; Plecoptera) taxonomic research in Alabama, with new state records and an updated checklist. Illiesia, 7(2):24-30. http://illiesia.speciesfile.org/ papers/Illiesia07-02.pdf

Grubbs, S.A. 2012. An amended redescription of the male of Perlesta etnieri (Plecoptera: Perlidae) plus new Perlesta state records. Illiesia, 8(9):111-113.
http://illiesia.speciesfile.org/papers/Illiesia08-09.pdf Grubbs, S.A. 2015. Leuctra schusteri, a new stonefly species (Plecoptera: Leuctridae) of the L. tenuis (Pictet) group from the southeastern USA. Illiesia, 11(12):147-166. http://illiesia.speciesfile.org/papers/Illiesia11-12.pdf Grubbs, S.A. \& A.L. Sheldon. 2008. Allocapnia muskogee and $A$. menawa, new species of snowflies (Plecoptera: Capniidae) from the Talladega National Forest region of eastern Alabama, USA, plus four new state records. Illiesia, 4(11):99-109. http://illiesia.speciesfile.org /papers/Illiesia04-11.pdf

Grubbs, S.A. \& R.E. DeWalt. 2008. Taxonomic and distributional notes on Perlesta teaysia, $P$. golconda, and P. shawnee (Plecoptera: Perlidae). Illiesia, 4(14):143-149. Illiesia, 4(14):143-149. http://illiesia.speciesfile.org/papers/llliesia04-14.pdf

Grubbs S.A. \& R.E. DeWalt. 2012. Perlesta ephelida, a new Nearctic stonefly species (Plecoptera, Perlidae). ZooKeys 194: 1-15. doi: 10.3897/zookeys.194.2972

Grubbs, S.A., B.C. Kondratieff, B.P. Stark \& R.E. DeWalt. 2013. A review of the Nearctic genus Zealeuctra Ricker (Plecoptera, Leuctridae), with the description of a new species from the Cumberland Plateau region of eastern North America. ZooKeys, 344:17-47. https://doi.org/10.3897/zookeys.344.5912

Grubbs, S.A., M. Pessino \& R.E. DeWalt. 2012. Michigan Plecoptera (stoneflies): distribution patterns and an updated species list. Illiesia, 8(18):162-173. http://illiesia.speciesfile.org/papers/ Illiesia08-18.pdf

Grubbs, S.A., R.W. Baumann, R.E. DeWalt \& T. Tweddale. 2014. A review of the Nearctic genus Prostoia (Ricker) (Plecoptera, Nemouridae), with the description of a new species and a surprising range extension for $P$. hallasi Kondratieff \& Kirchner. ZooKeys, 401:11-30. https://doi.org/10.3897/zookeys.401.7299

Harper, P.P. \& H.B.N. Hynes. 1971. The Leuctridae of eastern Canada (Insecta; Plecoptera). Canadian Journal of Zoology, 49(6):915-920. http://www.nrcresearchpress.com/doi/pdf/10.11 39/z71-136

Harrison, A.B. \& B.P. Stark. 2010. Two new species of stoneflies in the Leuctra ferruginea group 
Verdone, C.J., B. Kondratieff, R.E. DeWalt, and E. South. 2017. Studies on the stoneflies of Georgia with the description of a new species of Soyedina Ricker, new state records and an annotated checklist. Illiesia, 13(03):30-49. https://doi.org/10.25031/2017/13.03

(Plecoptera: Leuctridae), with notes on the Leuctra species known for Mississippi and Alabama, U.S.A. Illiesia, 6(03):16-33. http://illiesia.speciesfile.org/papers/llliesia06-03.pdf James, A.M. 1972. The stoneflies (Plecoptera) of Alabama. Unpublished Doctoral dissertation, Auburn University, Auburn, Alabama. 169 pp.

Kondratieff, B.C. \& C.H. Nelson. 1995. A review of the genus Remenus Ricker (Plecoptera: Perlodidae), with the description of two new species. Proceedings of the Entomological Society of Washington, 97(3): 596-602.

Kondratieff, B.C. \& R.F. Kirchner. 1987. Additions, taxonomic corrections, and faunal affinities of the stoneflies (Plecoptera) of Virginia, USA. Proceedings of the Entomological Society of Washington, 89:24-30.

http://www.biodiversitylibrary.org/page/16262424

Kondratieff, B.C. \& R.F. Kirchner. 2002. Perlesta etnieri (Plecoptera: Perlidae), a new species of stonefly from Tennessee. Proceedings of the Entomological Society of Washington, 104:51-55. http://www.biodiversitylibrary.org/page/16173598

Kondratieff, B.C., C.J. Verdone \& S. Roble. 2017. New records of stoneflies (Plecoptera) from Virginia, U.S.A. Perla, 35:22-27. http://plecoptera.speciesfile.org/HomePage/Plec optera/LitArchive/PerlaNo35_2017.pdf

Kondratieff, B.C., R.F. Kirchner \& D.R. Lenat. 1995. A review of stonefly records (Plecoptera: Hexapoda) of North Carolina and South Carolina. Brimleyana, (23):25-40. https://www.researchgate.net/publication/26763 1352_A_Review_of_Stonefly_Records_Plecopter a_Hexapoda_of_North_Carolina_and_South_C arolina

Lenat, D.R., R.E. Zuellig B.C. Kondratieff \& S.R.

Beaty. 2009. Distribution of Neoperla (Plecoptera: Perlidae) in North Carolina, with new state records for three species. Illiesia, 5(15):164-168. http://illiesia.speciesfile.org/papers/Illiesia0515.pdf

Lund, H.O. 1954. Perry Wilbur Fattig 1881-1953. Journal of Economic Entomology, 47(2):352. https://doi.org/10.1093/jee/47.2.352

Myers, L.W. \& B.C. Kondratieff. 2009. Descriptions of the nymphs of eastern North Americans of Cultus (Plecoptera: Perlodidae). New York
Entomological Society, 115(2):109-114.

Needham, J.G. \& L.W. Smith. 1916. The stoneflies of the genus Peltoperla. The Canadian Entomologist, 48(3):80-88.

Needham, J.G. \& P.W. Claassen. 1925. Monograph of the Plecoptera or stoneflies of America, north of Mexico. Entomological Society of America, Thomas Say Foundation, 2:1-397.

Nelson, C.H. 1982. Notes on the life histories of Strophopteryx limata (Frison) and Oemopteryx contorta (Needham and Claassen) (Plecoptera: Taeniopterygidae) in Tennessee. Journal of the Tennessee Academy of Science, 57:9-15.

Nelson, C.H. \& J.F. Hanson. 1971. Contribution to the anatomy and phylogeny of the family Pteronarcyidae (Plecoptera). Transactions of the American Entomological Society, 97(1):123-200.

Newman, E. 1838. Entomological notes. The Magazine of Natural History, 5:168-181, 372402, 483-500.

Newman, E. 1839. On the synonymy of the Perlites, together with brief characters of the old, and of a few new species. The Magazine of Natural History, 3:32-37, 84-90.

Parker, C.R., O.S. Flint Jr., L.M. Jacobus, B.C. Kondratieff, W.P. McCafferty \& J.C. Morse. 2007. Ephemeroptera, Plecoptera, Megaloptera, and Trichoptera of Great Smoky Mountains National Park. Southeastern Naturalist, 6(sp2):159-174. https://www.jstor.org/stable/pdf/4541006.pdf

Ricker, W.E. 1938. Notes on specimens of American Plecoptera in European collections. Transactions of the Royal Canadian Institute, 22(1):129-156.

Ricker, W.E. 1949. The North American species of Paragnetina (Plecoptera, Perlidae). Annals of the Entomological Society of America, 42(3):279-288. https://doi.org/10.1093/aesa/42.3.279

Ricker, W.E. 1952. Systematic studies of Plecoptera. Indiana University Publications Science Series, 18:1-200. http://www.nativefishlab.net/library/ textpdf/16861.pdf

Ricker, W.E. \& H.H. Ross. 1968. North American species of Taeniopteryx (Plecoptera, Insecta). Journal of the Fisheries Board of Canada, 25(7): 1423-1439.

Ross, H.H. \& W.E. Ricker. 1971. The classification, evolution, and dispersal of the winter stonefly genus Allocapnia. Illinois Biological Monographs 
Verdone, C.J., B. Kondratieff, R.E. DeWalt, and E. South. 2017. Studies on the stoneflies of Georgia with the description of a new species of Soyedina Ricker, new state records and an annotated checklist. Illiesia, 13(03):30-49. https://doi.org/10.25031/2017/13.03

45. University of Illinois Press, Urbana, Illinois. 166 pp. http://www.ideals.illinois.edu/bitstream /handle/2142/27332/classificationev45ross.pdf

Stark, B.P. 1986. The Nearctic species of Agnetina (Plecoptera: Perlidae). Journal of the Kansas Entomological Society, 59:437-445. http://www.jstor.org/stable/pdf/25084804.pdf

Stark, B.P. 1989. Perlesta placida (Hagen), an eastern Nearctic species complex (Plecoptera: Perlidae). Insect Systematics \& Evolution, 20(3):263-286.

Stark, B.P. 1990. Neoperla clymene revisited: systematics of the Nearctic species complexes (Plecoptera: Perlidae). Pp. 299-310. In: Mayflies and stoneflies life histories and biology: proceedings of the 5th International Ephemeroptera Conference and the 9th International Plecoptera Conference. Campbell, I.C. (Ed.) (Vol. 44). Kluwer Academic Publishers, 366 pp. https://ink.springer.com/content/pdf/10.1007\% 2F978-94-009-2397-3.pdf

Stark, B.P. 2004. Perlidae (The Stones) Pp. 61-148. In: Stoneflies (Plecoptera) of eastern North America, Volume II, Chloroperlidae, Perlidae, and Perlodidae (Perlodinae). B.P. Stark, B.J. Armitage (Eds.) Bulletin of the Ohio Biological Survey, Columbus, Ohio. 192 pp.

Stark, B.P., A.B. Harrison \& K.C. Nye. 2016. Records of an uncommon stonefly, Nemocapnia carolina Banks (Plecoptera: Capniidae), in South Carolina and nearby states. Illiesia, 12(02):10-14. http://illiesia.speciesfile.org/papers/Illiesia12-02.pdf

Stark, B.P. \& A.R. Gaufin. 1976. The Nearctic species of Acroneuria (Plecoptera: Perlidae). Journal of the Kansas Entomological Society, 49(2):221-253. http://www.jstor.org/stable/pdf/25082817.pdf

Stark, B.P. \& D.H. Ray. 1983. A revision of the genus Helopicus (Plecoptera: Perlodidae). Freshwater Invertebrate Biology, 2(1):16-27.

Stark, B.P. \& J.W. Kyzar. 2001. Systematics of Nearctic Paraleuctra with description of a new genus (Plecoptera: Leuctridae). Tijdschrift voor Entomologie, 144(1):119-135.

Stark, B.P. \& R.W. Baumann. 2004. The winter stonefly genus Paracapnia (Plecoptera: Capniidae). Monographs of the Western North American Naturalist, 2(1):96-108.

Stark, B.P., S.W. Szczytko \& R.W. Baumann. 1986. North American stoneflies (Plecoptera): systematics, distribution, and taxonomic references. Great Basin Naturalist, 46:383-397. https://www.jstor.org/stable/pdf/41712245.pdf

Stark, B.P., S.W. Szczytko \& B.C. Kondratieff. 1988. The Cultus decisus complex of eastern North America (Plecoptera: Perlodidae). Proceedings of the Entomological Society of Washington, 90(1):91-96. http://www.biodiversitylibrary.org/ page/16144505

Stewart, K.W. \& B.P. Stark. 1988. Nymphs of North American stonefly genera (Plecoptera). Entomological Society of America. Thomas Say Foundations, Entomological Society of America Monographs, 12.460 pp.

Stewart, K.W. \& B.P. Stark. 2002. Nymphs of North American stonefly genera (Plecoptera). University of North Texas Press (reprint). 400 pp. Stewart, K.W. \& B.P. Stark. 2002. Nymphs of North American stonefly genera (Plecoptera). Second Edition. The Caddis Press. Columbia, Ohio. xii + $510 \mathrm{p}$.

Surdick, R.F. 1985. Nearctic genera of Chloroperlinae (Plecoptera: Chloroperlidae). Illinois Biological Monographs 54. University of Illinois Press, Urbana, Illinois. 146 pp.

Surdick, R.F. 2004. Chloroperlidae (The Sallflies). Pp. 1-60. In: Stoneflies (Plecoptera) of eastern North America, Volume II, Chloroperlidae, Perlidae, and Perlodidae (Perlodinae). B.P. Stark, B.J. Armitage (Eds.) Bulletin of the Ohio Biological Survey, Columbus, Ohio. 192 pp.

Szczytko, S.W. \& B.C. Kondratieff. 2015. A review of the eastern Nearctic Isoperlinae (Plecoptera: Perlodidae) with the description of twenty-two new species. Monographs of Illiesia, Number 1:1-289. http://illiesia.speciesfile.org/papers/ Monographiae-of-Illiesia.pdf 
Verdone, C.J., B. Kondratieff, R.E. DeWalt, and E. South. 2017. Studies on the stoneflies of Georgia with the description of a new species of Soyedina Ricker, new state records and an annotated checklist. Illiesia, 13(03):30-49. https://doi.org/10.25031/2017/13.03

Verdone, C.J. \& B. Kondratieff. 2016. A new species Isoperla Banks (Plecoptera: Perlodidae) from the Appalachian Mountains, Virginia \& West Virginia, U.S.A. Illiesia, 12(13):74-85. http://illiesia.speciesfile.org/papers/Illiesia1213.pdf

Unzicker, J.D. \& V.H. McCaskill. 1982. Plecoptera. Pp. 5.1-5.50. In: Aquatic insects and oligochaetes of North and South Carolina. A.R. Brigham, W.U. Brigham \& A. Gnilka (Eds.) Midwest Aquatic Enterprises, Mahomet, Illinois.
Woodward, S.L. \& R.L. Hoffman. 1991. The nature of Virginia. Pp. 23-48. In: Virginia's endangered species: Proceedings of a symposium. K. Terwilliger (coordinator). McDonald \& Woodward Publishing Company. Blacksburg, Virginia. $672 \mathrm{pp}$.

Appendix A. List of sampling locations from Georgia 2016-2017.

\begin{tabular}{|c|c|c|c|c|c|}
\hline $\begin{array}{l}\text { Physiographic } \\
\text { Province }\end{array}$ & County & Habitat & Location & Latitude & Longitude \\
\hline Appalachian Plateau & Dade & Bear Creek & SR 189, Cloudland State Park & 34.82823 & -85.45934 \\
\hline Appalachian Plateau & Dade & Daniel Creek & Cloudland State Park & 34.82457 & -85.49074 \\
\hline Appalachian Plateau & Walker & West Chickamauga Creek & SR 136 & 34.80250 & -85.34884 \\
\hline Blue Ridge & Dawson & Little Amicalola Creek & Amicalola Falls State Park & 34.57233 & -84.24107 \\
\hline Blue Ridge & Fannin & Noontootla Creek & $10.4 \mathrm{~km}$ NNE Amicalola Mtn. at FS Rd. 58 & 34.68791 & -84.20182 \\
\hline Blue Ridge & Fannin & Noontootla Creek & 8.9 km NNE Amicalola Mtn. & 34.67289 & -84.19695 \\
\hline Blue Ridge & Fannin & Noontootla Creek & $9.0 \mathrm{~km}$ NNE Amicalola Mtn. & 34.67347 & -84.19692 \\
\hline Blue Ridge & Fannin & Seep along FS 58 & 10.4 km NNE Amicalola Mtn. & 34.68595 & -84.19587 \\
\hline Blue Ridge & Fannin & Toccoa River & 16.0 km SE Blue Ridge at GA-5 & 34.75758 & -84.20606 \\
\hline Blue Ridge & Gilmer & Rock Creek & $12.6 \mathrm{~km}$ NE Ellijay at US-76 & 34.77922 & -84.39091 \\
\hline Blue Ridge & Gilmer & Rock Creek & Rock Creek Rd. & 34.78176 & -84.33619 \\
\hline Blue Ridge & Lumpkin & Frogtown Creek & Hwy 19, Desoto Falls Rec. Area & 34.70649 & -83.91634 \\
\hline Blue Ridge & Lumpkin & Nimblewill Creek & Nimblewill Gap Rd. & 34.56536 & -84.14637 \\
\hline Blue Ridge & Murray & Conasauga River & Old Hwy 2 & 34.97461 & -84.64487 \\
\hline Blue Ridge & Murray & Holly Creek & Camp Rd. Day Use Area & 34.81181 & -84.66080 \\
\hline Blue Ridge & Murray & Jigger Creek & East Cowpen Rd. & 34.96260 & -84.63861 \\
\hline Blue Ridge & Rabun & Chattooga River & Hwy 76 Fishing Access & 34.81404 & -83.30647 \\
\hline Blue Ridge & Rabun & Greasy Creek & North Germany Rd. & 34.91460 & -83.41972 \\
\hline Blue Ridge & Rabun & North Fork Chattooga River & Hwy 28 & 34.92010 & -83.16924 \\
\hline Blue Ridge & Towns & headwaters of Soapstone Creek & $1.5 \mathrm{~km}$ SSE Brasstown Bald & 34.85994 & -83.80254 \\
\hline Blue Ridge & Towns & Soapstone Creek & 2.9 km SE Brasstown Bald & 34.85588 & -83.78517 \\
\hline Blue Ridge & Union & Wolf Creek & Vogel S.P. at Burnette Branch & 34.76311 & -83.92679 \\
\hline Blue Ridge & Union & Left Fork Nottely River & 8.1 km NNW Pinnacle Mountain & 34.75055 & -83.84511 \\
\hline Blue Ridge & Union & Nottely River & 8.0 km NNW Pinnacle Mountain & 34.74962 & -83.84646 \\
\hline Blue Ridge & White & Tributary to Dukes Creek & $11.4 \mathrm{~km} \mathrm{~N}$ Cleveland & 34.69804 & -83.78149 \\
\hline Coastal Plain & Bleckley & Ocmulgee River & James Dykes Park & 32.41439 & -83.48319 \\
\hline Coastal Plain & Houston & Burnham Brand Creek & Hwy 26, SE of Elko & 32.31585 & -83.66442 \\
\hline
\end{tabular}


Verdone, C.J., B. Kondratieff, R.E. DeWalt, and E. South. 2017. Studies on the stoneflies of Georgia with the description of a new species of Soyedina Ricker, new state records and an annotated checklist. Illiesia, 13(03):30-49. https://doi.org/10.25031/2017/13.03

\begin{tabular}{|c|c|c|c|c|c|}
\hline Coastal Plain & Macon & Flint River & Montezuma Bluffs Park & 32.33682 & -84.03118 \\
\hline Coastal Plain & Stewart & Hannahatchee Creek & Co Rd. 150 & 32.14157 & -84.75333 \\
\hline Piedmont Plateau & Greene & Fishing Creek & Hwy 15 & 33.66975 & -83.26152 \\
\hline Piedmont Plateau & Greene & Harris Creek & Nichols Rd. & 33.72509 & -83.23737 \\
\hline Piedmont Plateau & Greene & Oconee River & Hwy 15, Oconee NF campground & 33.72149 & -83.29095 \\
\hline Piedmont Plateau & Habersham & trib. to Lake Russell & Lake Russell Rd. & 34.50077 & -83.48914 \\
\hline Piedmont Plateau & Paulding & Bluffy Creek & Hulsey Town Rd. & 33.89260 & -84.92486 \\
\hline Piedmont Plateau & Paulding & trib. to Pumpkinvine Creek & Hulsey Town Rd. & 33.90456 & -84.91684 \\
\hline Piedmont Plateau & Pickens & Talking Rock Creek & $6.3 \mathrm{~km}$ WNW Talking Rock at GA-136 & 34.52624 & -84.57093 \\
\hline Piedmont Plateau & Putnam & Big Indian Creek & Big Indian Creek Rd. & 33.39687 & -83.47433 \\
\hline Piedmont Plateau & Putnam & Little River & Glades Rd. & 33.37248 & -83.47730 \\
\hline Piedmont Plateau & Putnam & Murder Creek & Hillsboro Rd. & 33.26861 & -83.49739 \\
\hline Piedmont Plateau & Putnam & Rock Creek & Rock Creek Rd. & 34.78176 & -84.33619 \\
\hline Piedmont Plateau & Upson & Flint River & Sprewell Bluff Park & 32.85381 & -84.48034 \\
\hline Ridge and Valley & Floyd & Johns Creek & Everett Springs Rd. S of Camp Sydney Drew & 34.52889 & -85.11405 \\
\hline Ridge and Valley & Floyd & Johns Creek & Everett Springs Rd. & 34.56416 & -85.10104 \\
\hline Ridge and Valley & Floyd & trib. to Johns Creek & FR 103, The Pocket Rec. Area & 34.58443 & -85.08587 \\
\hline Ridge and Valley & Murray & Head Branch & Old Hwy 2, 2 mi. E of Cisco & 34.94477 & -84.71942 \\
\hline Ridge and Valley & Murray & trib. to Conasauga River & East Cowpen Rd. & 34.95390 & -84.67750 \\
\hline Ridge and Valley & Walker & Snake Creek & SR 138, S. of Snake Creek Gap & 34.64711 & -85.06106 \\
\hline Ridge and Valley & Walker & trib. to Johns Creek & Keown Falls Trail & 34.61380 & -85.08757 \\
\hline
\end{tabular}

Submitted 19 July 2017, Accepted 10 August 2017, Published 28 August 2017

Hosted and published at the University of Illinois, Illinois Natural History Survey, Champaign, Illinois, U.S.A. 